\title{
Islamic Thought in Africa
}




\section{WORLD THOUGHT IN TRANSLATION}

A joint project of Yale University Press and the MacMillan Center for International and Area Studies at Yale University, World Thought in Translation makes important works of classical and contemporary political, philosophical, legal, and social thought from outside the Western tradition available to English-speaking scholars, students, and general readers. The translations are annotated and accompanied by critical introductions that orient readers to the background in which these texts were written, their initial reception, and their enduring influence within and beyond their own cultures. World Thought in Translation contributes to the study of religious and secular intellectual traditions across cultures and civilizations.

\section{SERIES EDITORS}

Stephen Angle

Andrew March

Ian Shapiro 


\title{
Islamic Thought in Africa
}

\author{
The Collected Works of Afa Ajura (1910-2004) \\ and the Impact of Ajuraism on Northern Ghana
}

\author{
Alhaj Yūsuf Șāliḥ Ajura (Afa Ajura) \\ Translated by Zakyi Ibrahim
}

\author{
Yale \\ UNIVERSITY \\ PRESS
}

New Haven \& London 
This publication was made possible in part by a grant from the Carnegie Corporation of New York. The statements made and views expressed are solely the responsibility of the author.

Published with assistance from the foundation established in memory of Philip Hamilton McMillan of the Class of 1894, Yale College.

Afa Ajura's original works copyright (C) by the Estate of Afa Ajura. English translation and introduction copyright (C) 2021 by Zakyi Ibrahim.

All rights reserved.

This book may not be reproduced, in whole or in part, including illustrations, in any form (beyond that copying permitted by Sections 107 and 108 of the U.S. Copyright Law and except by reviewers for the public press), without written permission from the publishers.

Yale University Press books may be purchased in quantity for educational, business, or promotional use. For information, please email sales .press@yale.edu (U.S.office) or sales@yaleup.co.uk (U.K. office).

Set in Electra type by Newgen North America.

Printed in the United States of America.

Library of Congress Control Number: 2020951712 ISBN 978-o-300-20711-8 (hardcover : alk. paper)

A catalogue record for this book is available from the British Library.

This paper meets the requirements of ANSI/NISO Z39.48-1992 (Permanence of Paper).

10987654321 
To my parents, Mba Alahji Ibrambila and Mma Maata, and to Afa Ajura, with immense appreciation and respect 


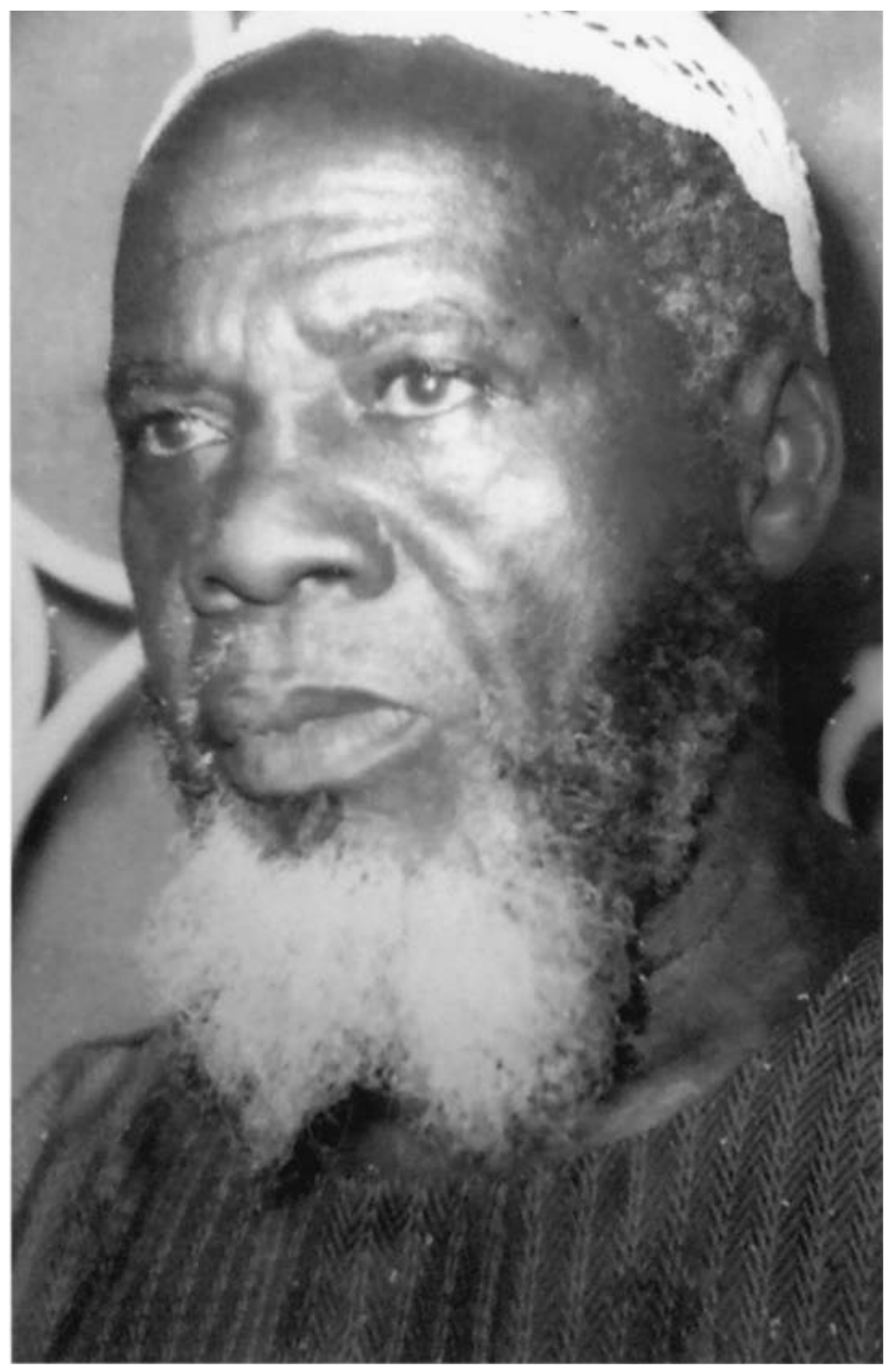

Afa Ajura in his "wisdom posture." Credit for this photo goes to Afa Seidu and Afa Ahmad, Afa Ajura's foster child and son, respectively. 